Ann. Biol. anim. Bioch. Biophys., 1979, 19 (6), 1655-1667.

\title{
Increase of follicle cell LH binding and changes in the Lì level of follicular fluid during the preovulatory period in the sow
}

\author{
par Marie-Christine DAGUET
}

Station centrale de Physiologie animale, I. N. R. A., 78350 Jouy-en-Josas and Université Pierre et Marie Curie, Paris VI, France.

\begin{abstract}
Summary. This study used the fechnique of histoautoradiography to analyze the variation of $\mathrm{LH}$ binding in sow follicles during the preovulatory period. Estrus was synchronized by methallibure to obtain a reference point for dating the onset of the follicular phase of each sow in the experiment. In follicles increasing in diameter from $2.6 \mathrm{~mm}$ at days 0 and 1 of the follicular phase to $6.6 \mathrm{~mm}$ at day 6 , granulosa ${ }^{125}$-oLH or ${ }^{125}$-pLH binding increased by 14 times while that of the theca interna increased by 2 . The binding of these hormones remained high during and after the end of the ovulatory LH surge, at least until several hours before ovulation. Variations in plasmic as well as intrafollicular LH levels were radioimmunologically assayed. High intrafollicular levels of estradiol-17 $\beta$ at day 3 would explain the large increase of granulosa LH binding between days 4 and 5-6, in turn causing the intrafollicular level of progesterone to rise at day 5 . These results indicated an interdependence between hormonal levels and target cell receptivity.
\end{abstract}

\section{Introduction.}

Gonadotropins induce the growth and maturation of follicles and oocytes by binding to the membrane receptors. Thus, during follicular growth in rats, receptors appear in the granulosa: FSH receptors are seen first, and then, under the action of that gonadotropin, LH receptors appear (Zeleznick ef al., 1974 ; Richards ef al., 1976 ; Nimrod et al., 1977). Concomitantly, the follicular fluid is first rich in FSH then in LH (women : McNatty ef al., 1975). Gonadotropic action in the granulosa is thus sequential, while the theca interna always appears to bind $\mathrm{LH}$.

Since these data cannot be generalized from a small number of species, this report studies $\mathrm{LH}$ receptor variation and the intrafollicular penetration of this hormone in sows.

Most of the work on follicular receptors uses tissue homogenate preparation. For instance, Kammerman and Ross (1975), Stouffer et al. (1976), and Lee (1976) 
used homogenates of granulosa cells obtained by needle aspiration from the follicles of pig ovaries. This technique is the only one permitting a determination of the physicochemical constants of binding. However, the receptors cannot be localized in the tissues, and thus the theca externa and the theca interna are not usually studied. Moreover, any variations which might exist in the number of receptors on the external or internal granulosa layers cannot be detected, and atretic follicles cannot be distinguished from healthy ones. This study attempts to obtain data on the position and the quantity of follicular LH receptors during final follicular growth (the several days preceding the appearance of estrus and the several hours afterwards, i.e. almost up to ovulation) by using the technique of histoautoradiography.

\section{Material and methods.}

Cycling hybrid (Large-White $\times$ Landrace) sows received an estrus synchronization treatment (Polge, 1965) during which they were given methallibure for 20 days. In addition, 2 untreated sows were used as controls. The methallibure treatment was used to obtain a point of reference so that the onset of the follicular phase of each sow could be dated. Methallibure, while acting on the hypothalamo-pituitary axis, inhibits the release of gonadotropins and follicular growth is thus blocked; it resumes after the treatment is withdrawn, and thus at a knonw date.

Heat was detected with a boar twice a day at 8:00 a.m. and 4:30 p.m. The sows came into heat between day $51 / 2$ (D51/2) and day 8 (D 8) after methallibure withdrawal. Ovulation thus occurred between days 7 and 10 , depending on the animal.

Each day after the treatment was withdrawn, the ovaries were taken from 1 to 6 sows ; blood was collected after slaughter or under anesthesia.

In order to study LH binding after ovulatory LH surge, 2 sows were slaughtered $32 \mathrm{hrs}$ after the onset of estrus to be sure that the surge had ended (plasma LH assays of semi-continuous blood sampling had shown that the ovulatory LH surge appeared within 10 hours after the onset of estrus and lasted less than $20 \mathrm{hrs}$ ).

Since they were sur to be healthy, only the largest follicles of each ovary were used in all the experiments described (Daguet, 1978).

After the follicle diameter had been evaluated with a binocular lens, the follicular fluid was aspirated from some follicles with a microsyringe about $10 \mathrm{~min}$ after the ovary had been removed. The fluid was stored at $-20^{\circ} \mathrm{C}$ until assay. When the fluid volume of a follicle was too low to be assayed separately (at D1 and D2 when follicular diameter was small), the contents of several follicles of the same size, taken from the same ovary, were used. The plasma was obtained from blood collected as slaughter or during the operation by aspiration from the ear vein ; 0.2 p. 1000 of heparin at the most was added to the blood, which was then stored at $-20^{\circ} \mathrm{C}$ until assay.

Gonadotropin binding was studied using the autoradiog raphic technique described by Midgley (1973). The chloramine T method of Hunter and Greenwood (1962) modified by Kann (1972) was employed for labelling hormones. Ovine or porcine LH labelled with ${ }^{125}$ jodine $\left({ }^{125}\left|-o L H,{ }^{125}\right|-p L H\right)$, having a specific radioactivity of about $90 \mu \mathrm{Ci} / \mu \mathrm{g}$, was applied for $45 \mathrm{~min}$ at $37^{\circ} \mathrm{C}$ to $10 \mu \mathrm{m}$ sections of ovary cut with a cryostat. 
$70 \mu \mathrm{l}$ of labelled hormone, diluted with a phosphate buffer to obtain a hormonal concentration of $2 \mathrm{ng} / 70 \mu \mathrm{l}$, was applied per section, $70 \mu \mathrm{l}$ representing the amount necessary to cover the whole surface of the section. In some cases, incubation was carried out with ${ }^{125} \mathrm{I}-\mathrm{oLH}$ and an excess of non-radioactive oLH to study binding specificity.

After incubation, the sections were washed in the phosphate buffered saline to which 0.05 p. 100 bovine serum albumin had beel, added, then fixed with formol vapor for $45 \mathrm{~min}$ and covered with Ilford K2 autoradiographic emulsion. They were exposed for 25 days at $+4^{\circ} \mathrm{C}$. The autoradiographs were developed with an Amidol developer, stained with Fast Nuclear Red, and then with Picro-Indigo-Carmine.

After measurement of the follicular diameters and histological analysis of silver grain distribution, the follicular binding of radioactive gonadotropins was quantified using the technique of Rogers (1961) : the number of silver grains on a section is estimated by measuring the amount of light which they reflect with epi-illumination using a Leitz MPV microspectrophotometer (X 95). The results were located in that portion of the graph where there was a linear relation between the silver grain number and the amount of reflected light. Each measurement was carried out on a square $3.5 \times 3.5 \mu$ surface, $3.5 \mu$ corresponding to about one-half the diameter of a granulosa cell. No significant differences were found between the measurements of different sections of the same follicle ; the intensity of follicle hormone binding was thus estimated using 60 measurements on a single section, 30 on the theca interna and 30 on the granulosa. Measurements were faken at regular intervals (about 1 out of 4 microscopic fields). The quantity of non-specific radioactivity found on the ovarian stroma was subtracted from the mean of the 30 measurements (expressed in arbitrary units) of the theca interna and of the granulosa.

The theca externa did not bind LH and LH binding to the cumulus oophorus and the oocyte has not been studied because serial sections could not be obtained with the cryostat.

Plasma and intrafollicular LH were assayed by radioimmunology using the technique of Kann (1972) modified in this study. Assay specificity was tested by a cross-reaction with porcine FSH which only reacted at 5 p. 1000 . The assay was sensitive because the low assayable limit was 0.15 or $0.3 \mathrm{ng} / \mathrm{ml}$, depending on the assay; the high limit was 50 or $100 \mathrm{ng} / \mathrm{ml}$. Assay reproducibility was not satisfactorily tested since the experimental conditions in this study varied from one assay to another : the standard plasmas used in successive assays gave different results in absolute values. Thus, only relative inter-assay variations were considered. (1973).

The steroids were assayed using the radioimmunological technique of Terqui et al.

\section{Results.}

Follicular diameter (fig. 1). - Mean diameter was $2.6 \mathrm{~mm}$ on day 0 (D0), the day the methallibure treatment was withdrawn; it then increased progressively to $10.4 \mathrm{~mm}$ on day 10 (D10). 


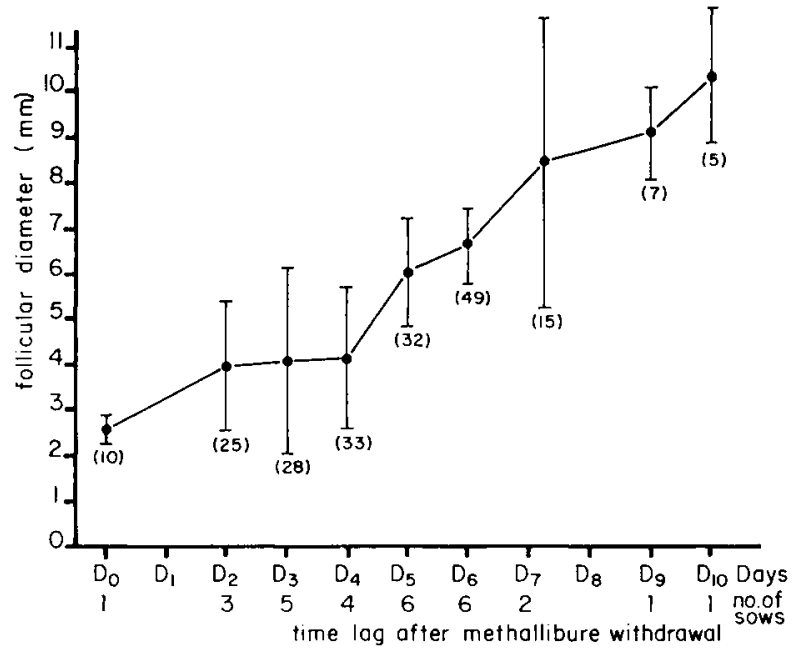

FIG. 1. - Variation of mean follicular diameters in relation to time lag after withdrawal of the methallibure treatment. Confidence interval : $\mathrm{P}=0.05 ;(-)$ : Number of follicles measured.

Follicular gonadotropin binding.

125|-oLH. Binding to the granulosa (fig. 2 ; photos 1,2) increased by 14 times between D0-D1 (sows $A$ and $B$ having a mean follicular diameter of $2.6 \mathrm{~mm}$ ) and D6 (sows $\mathrm{G}, \mathrm{H}, \mathrm{I}, \mathrm{J}, \mathrm{K}$ having a mean follicular diameter of $6.6 \mathrm{~mm}$ ). Although sow $\mathrm{C}$ was slaughtered on D1, the results were not used to obtain the mean at D0-D1 because

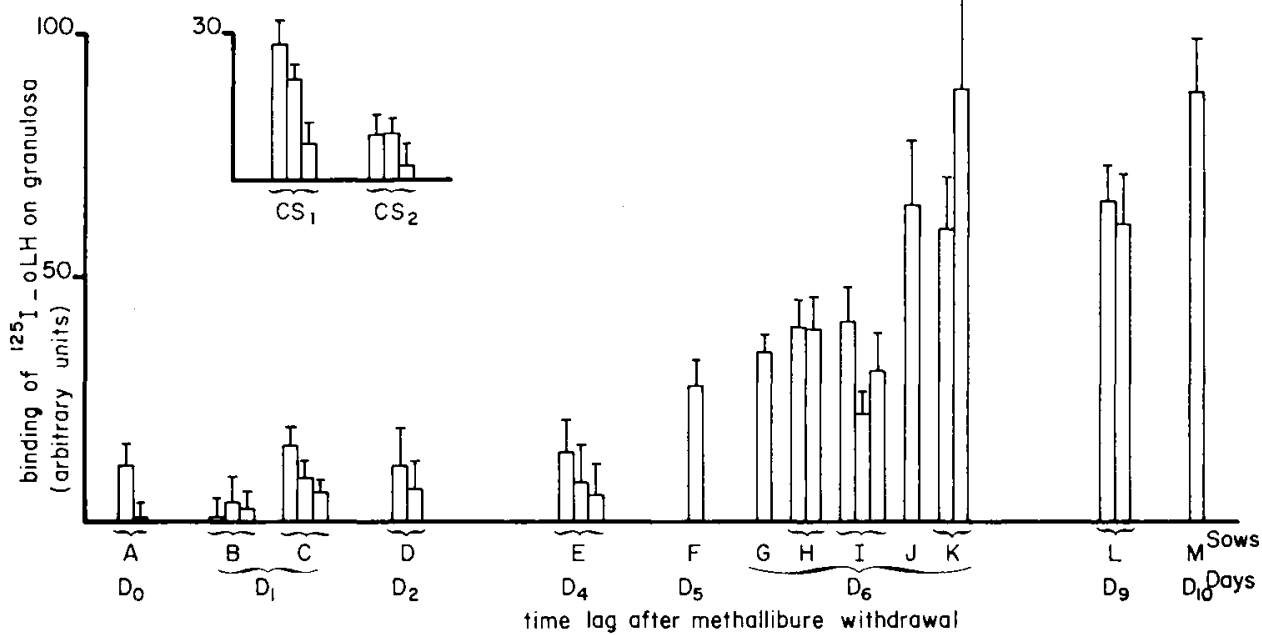

FIG. 2. - Variation of granulosa 125t-oLH binding in relation to time lag after withdrawal of the methallibure treatment and to the day of a spontaneous estrous cycle (CS) $\left(\mathrm{CS}_{1}=\right.$ day $16 ; \mathrm{CS}_{2}=$ day 17). $\mathrm{T}$ : mean of 30 measurements per follicle, from which non-specific labelling has been subtracted. Confidence interval: $\mathrm{P}=\mathbf{0 . 0 5}$. 

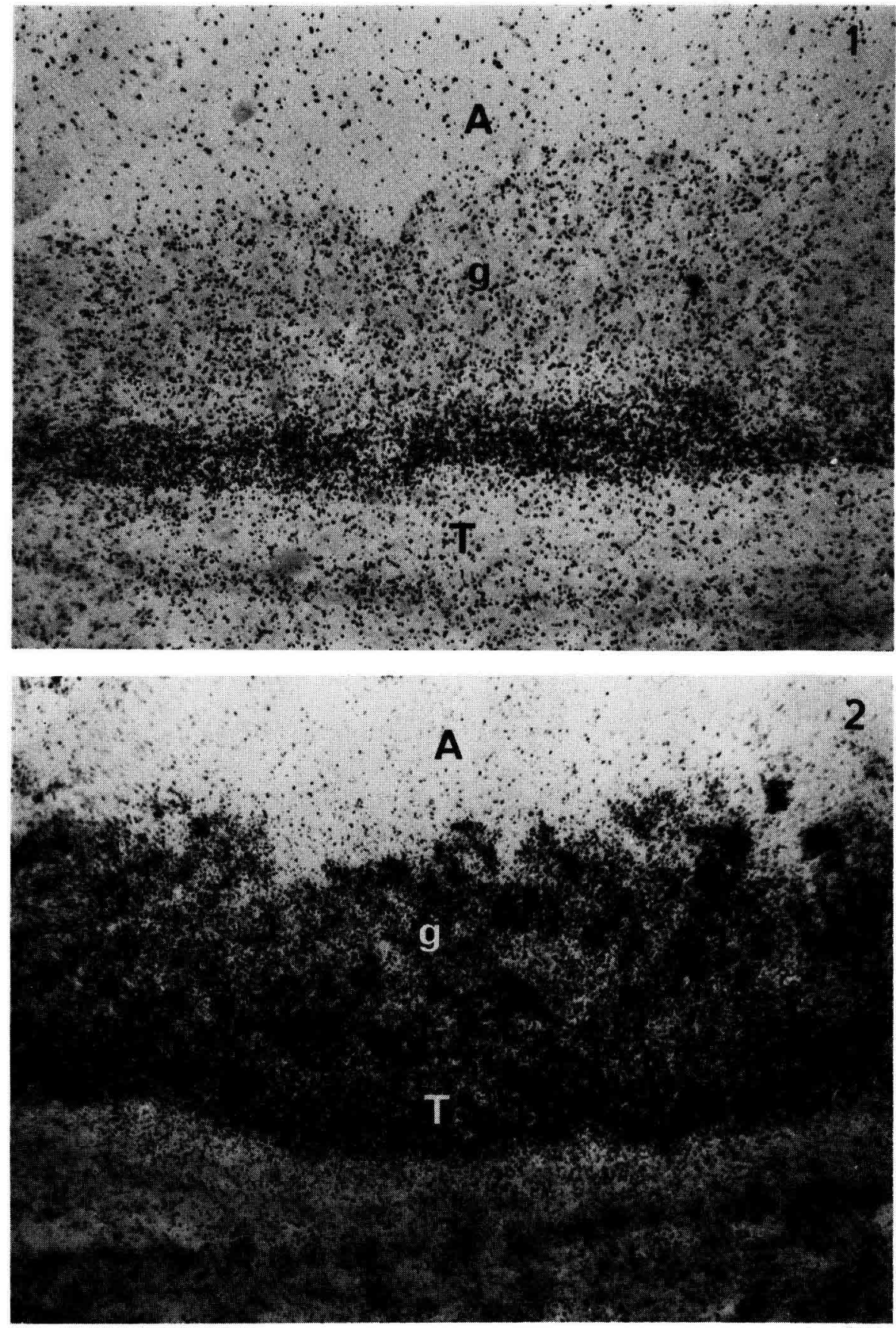

$\mathrm{T}$ : theca interna. $\mathrm{g}$ : granulosa. A : follicle antrum.

Plate I $\begin{aligned} & \text { Photo } 1 .- \text { Fixation of }{ }^{125} \text {-oLH on the follicular wall at D4 after methallibure withdrawal. } \\ & \quad \times 200 \text {. } \\ & \quad \times 200 \text {. Photo } 2 \text {. Fixation of }{ }^{125} \text {-oLH on the follicular wall at D6 after methallibure withdrawal. }\end{aligned}$ 
that animal had large follicles ( $4.3 \mathrm{~mm}$ diameter), which could have been classed as belonging to D2. ${ }^{125}$-oLH binding increased most between D4 and D5-6.

In the two sows $L$ and $M$ of D9 and D10, respectively, slaughtered about $32 \mathrm{hrs}$ after the onset of heat, ${ }^{125}$-oLH binding was as extensive as in sow $\mathrm{K}$ slaughtered at D6 before the ovulatory surge (the three sows $K, L$ and $M$ were used in the same experimental series; see below).

There was no difference in binding between the external layers of the granulosa, located near the basal lamina, and the internal layers near the follicular fluid.

In the theca interna (fig. 3 ; photos 1, 2) ${ }^{125}$-oLH binding increased by 2 times between D0-D1 (sows A and B) and D6 (sows G, H, I, J, K). Sows $L$ and $M$ showed as much ${ }^{125}$-oLH binding 32 hrs after the onset of heat as at D6 (sow K).

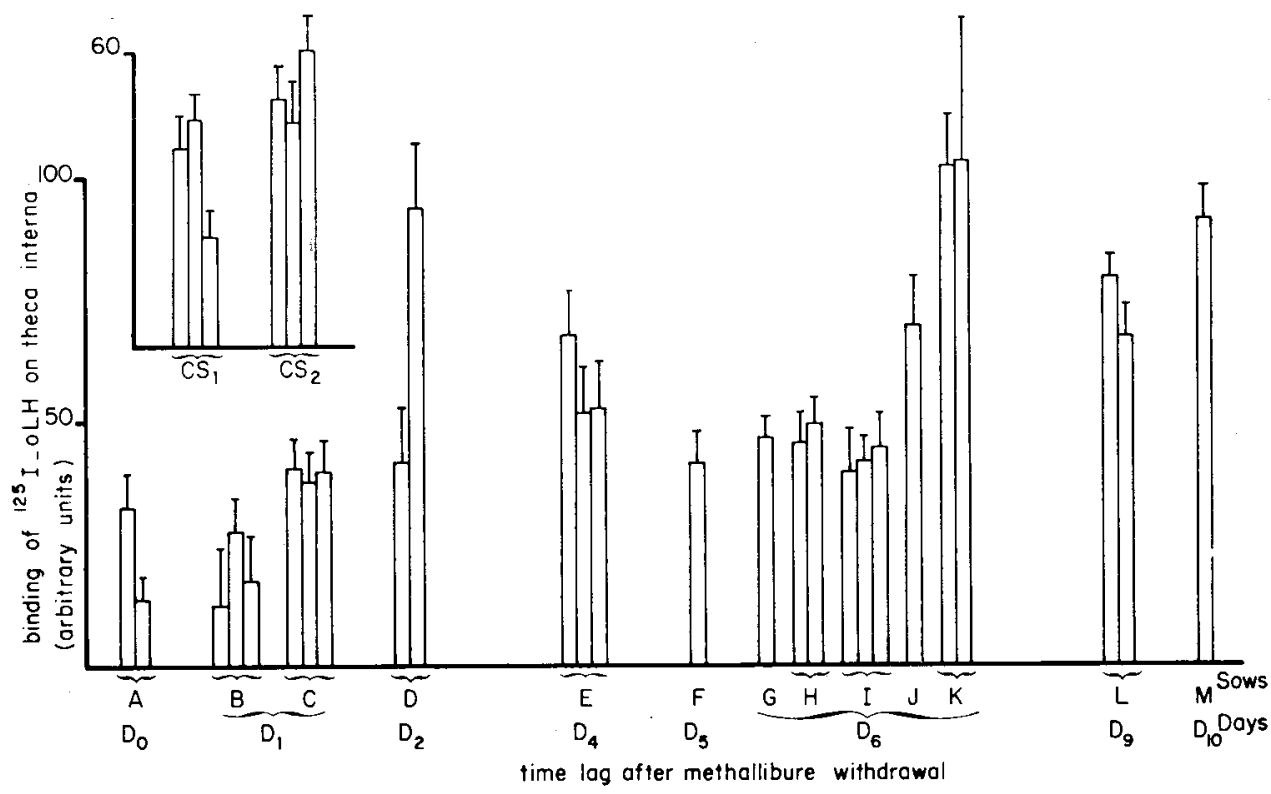

FIG. 3. - Variation of theca interna ${ }^{125}$-oLH binding in relation to time lag after withdrawal of the methallibure treatment and to the day of a spontaneous estrous cycle (CS) $\left(\mathrm{CS}_{1}=\right.$ day $16 ; \mathrm{CS}_{2}=$ day 17). $T$ : mean of 30 measurements per follicle, from which non-specific labelling has been subtracted. Confidence interval : $P=0.05$.

While there was little difference in binding between follicles of the same sow, there was wider variation in the follicles of several different sows slaughtered the same day (sows $B$ and $C$ of $D 1$; sows $G, H, I, J, K$ of D6). Four variables might be implicated :

- individual differences in the rate at which follicular activity was resumed after inhibition by the methallibure treatment;

- more or less exact assay of the methallibure, causing slight variations in the inhibition of gonadotropic activity ; 
- variability of the ${ }^{125}$-oLH, which showed slightly different specific radioactivity and biological activity at each labelling ;

- minor fechnical variations during the experiments, autoradiography being sensitive to many factors.

However, in spite of these variations, increased binding during the folli cular phase was sufficiently marked to be observed at least in the granulosa.

Figure 4 shows the change in the percentage of granulosa ${ }^{125} \mathrm{l}-\mathrm{oLH}$ binding as compared to that in the theca interna of the same follicle $(G / T \times 100)$ in relation to

FIG. 4. - Variation of the percentage of granulosa ${ }^{125}$-oLH binding as compared to that on the theca interna of the same follicle $(G / T \times 100)$ in relation to time lag after withdrawal of the methallibure treatment.

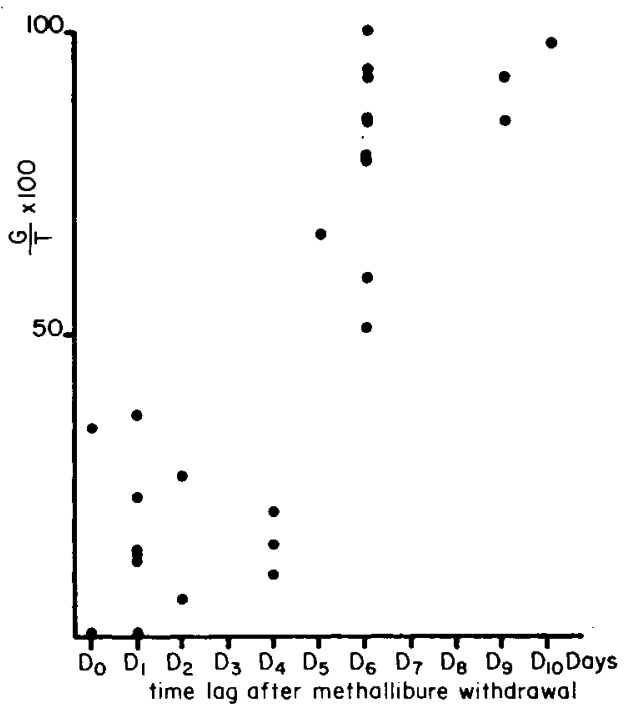

the time lag after the methallibure treatment was withdrawn. A difference appeared again between the first part of the follicular phase (D0 to D4), when the ${ }^{125}$-oLH bound to the granulosa never exceeded 36 p. 100 of that bound to the theca interna, and the second part of the phase (D5 to D10) when that percentage was usually higher than 50 p. 100.

There was competition between the ${ }^{125}$-oLH and the excess non-radioactive oLH for receptor saturation. This non-radioactive oLH caused the labelling to almost disappear (about a 92 p. 100 loss) on the theca interna and the granulosa (photo 3), thus demonstrating binding specificity.

The 2 control sows having a spontaneous estrous cycle and slaughtered at D16 and D17, respectively, showed the same binding rate in the granulosa (fig. 2) and the theca interna (fig. 3) as that observed in the methallibure-treated animals slaughtered at the same stage (D4). The methallibure treatment, therefore, did not appear to change follicular LH binding.

${ }^{125} \mid-p L H$. As the ${ }^{125}$-oLH, ${ }^{125} \mathrm{~L}-\mathrm{pLH}$ specifically bound to the theca interna and the granulosa, and the same quantitative variation in binding was found during the follicular phase. 


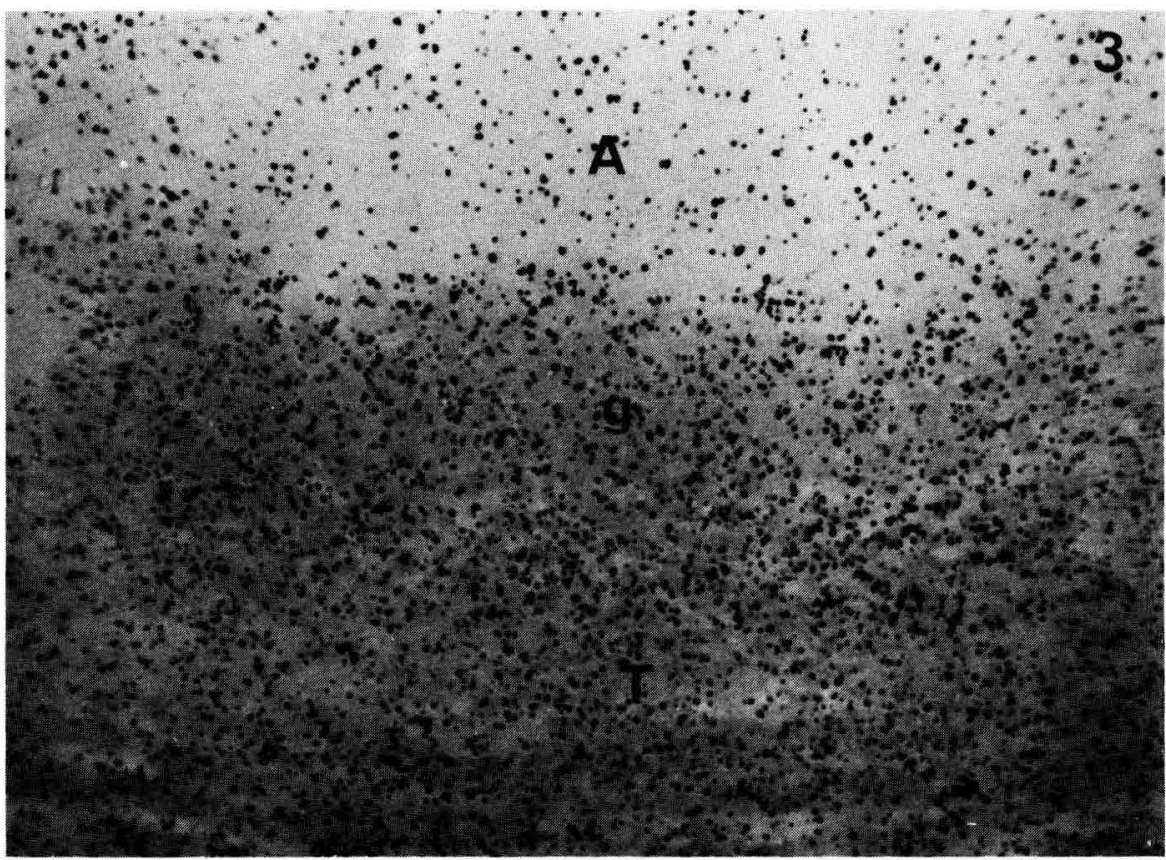
Plate II $\left\{\begin{array}{c}\text { Photo } 3 . \text { - Fixation of }{ }^{125} \text { l-oLH on the follicular wall in the presence of excess non-radio- } \\ \text { active oLH at D6 after methallibure withdrawal. } \times 200 .\end{array}\right.$

The follicle thus specifically bound $\mathrm{LH}$ whether it was homologous ( $\mathrm{PLH}$ ) or heterologous (oLH).

Variation of plasma and intrafollicular LH levels. - The highest, but most variable,

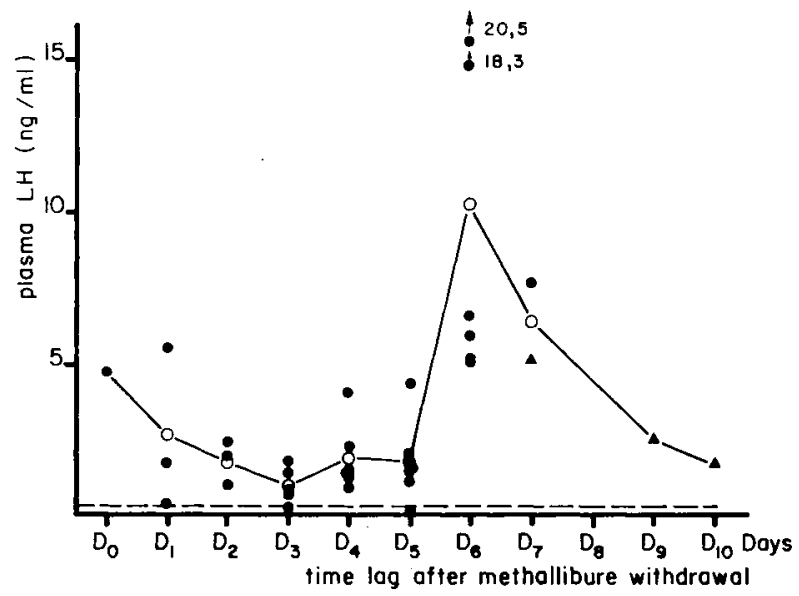

FIG. 5. - Variation of plasma LH in relation to time lag ofter withdrawal of the methallibure treatment. Each dof represents the value of one sow (๑). o : mean daily values; 1 : sows slaughtered at 24 hrs. (D7) and 32 hrs. (D9 and D10) after the onset of heat; - - - : lowest measurable value : $0.3 \mathrm{ng} / \mathrm{ml}$. 
plasma LH values were found at D6, showing individual differences in the time of ovulatory surge (fig. 5). The low values of the 2 sows slaughtered $32 \mathrm{hrs}$ after the onset of heat (at D9 and D10) indicated that the ovulatory surge had ended.

During the follicular phase, the highest intrafollicular LH levels occurred at D5 and D6 (fig. 6) ; they declined again after the ovulatory surge (sows slaughtered 24 and 32 hrs after the onset of heat).

FIG. 6. - Variation of intrafollicular LH in relation to time log ofter withdrawal of the methallibure treatment.

Each dot represents the value of one sow (e) : 1 to 3 follicles assayed per sow. 4 : sow slaughtered 24 hrs. (D7) after the onset of heat. - - : lowest measurable value : $0.15 \mathrm{ng} / \mathrm{ml}$.

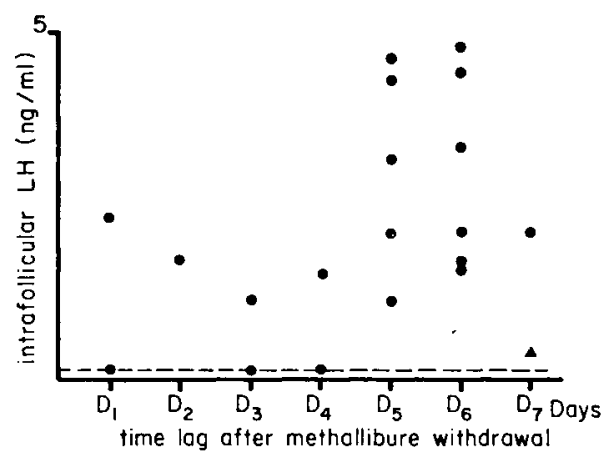

The numerical values of plasma and intrafollicular LH levels could not be compared because assay repeatability was not satisfactory (see Material and methods).

The LH contents of follicles from the same sow were homogeneous (less than 20 p. 100 variation), no matter what the day of slaughter (table 1 ). These results demonstrate that the follicles used (the largest ones in each ovary) were in the same physiological state.

TABLE 1

$\mathrm{LH}$ content $(\mathrm{ng} / \mathrm{ml})$ of 3 to 5 follicles from the same sow

\begin{tabular}{cccccc}
\hline \multirow{2}{*}{ Follicles } & \multicolumn{5}{c}{ Sows } \\
\cline { 2 - 6 } & $\mathrm{V}$ & $\mathrm{W}$ & $\mathrm{X}$ & $\mathrm{Y}$ & $\mathrm{Z}$ \\
\hline 1 & 1.97 & 2.59 & 0.64 & 1.83 & 2.14 \\
\hline 2 & 1.66 & 2.14 & 0.43 & 0.82 & 2 \\
\hline 3 & 1.35 & 1.78 & 0.68 & 1.94 & 1.55 \\
\hline 4 & 1.51 & & & 0.84 & 1.46 \\
\hline 5 & & & & & 2.09
\end{tabular}

Variation of intrafollicular estradiol-17 $\beta$ and progesterone levels. - High values were found from D3 for estradiol-17 $\beta$ (usually $100 \mathrm{ng} / \mathrm{ml}$ of follicular fluid ; fig. 7) and from $\mathrm{D} 5$ for progesterone $(150 \mathrm{ng} / \mathrm{ml} ;$ fig. 8). Progesterone remained high after 
the ovulatory LH surge had ended, while estradiol-17 $\beta$ values dropped earlier (low concentrations 24 and 32 hrs after the onset of heat).

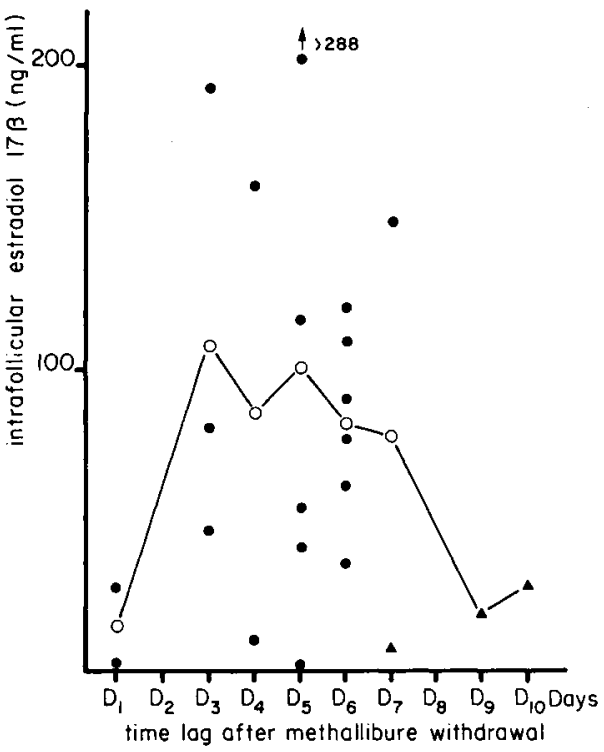

FIG. 7.

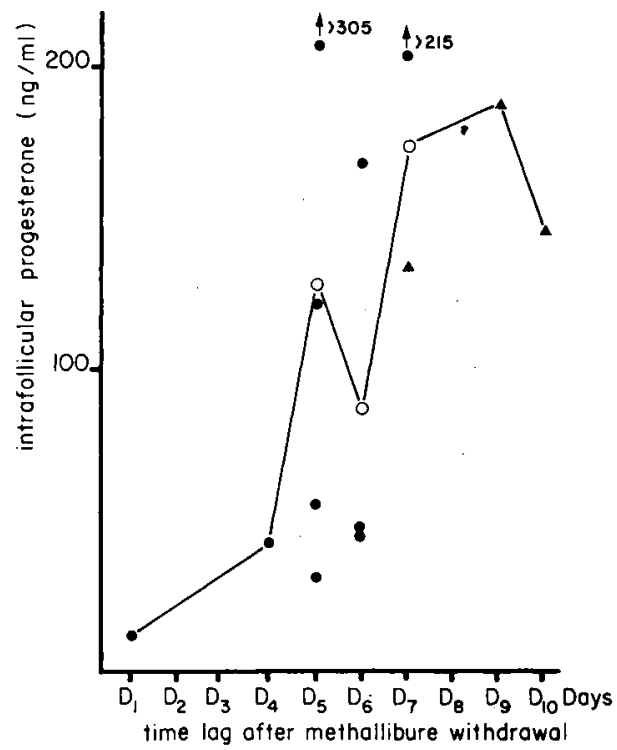

FIG. 8 .

FIG. 7. - Variation of intrafollicular estradiol-17 $\beta$ in relation to time lag after withdrawal of the methallibure treatment.

Each dot represents the value of one sow ( $\bullet$; 1 to 3 follicles assayed per sow. o : mean of daily values ; 4 : sows slaughtered 24 hrs. (D7) and 32 hrs. (D9 and D10) after the onset of heat. Lowest measurable value : $70 \mathrm{pg} / \mathrm{ml}$.

FIG. 8. - Variation of intrafollicular progesterone in relation to time lag after withdrawal of the methallibure treatment.

Each dot represents the value of one sow $(\bullet) ; 1$ to 3 follicles assayed per sow. $\circ$ : mean of daily values; 4 : sows slaughtered $24 \mathrm{hrs}$. (D7) and $32 \mathrm{hrs.} \mathrm{(D9} \mathrm{and} \mathrm{D10)} \mathrm{after} \mathrm{the} \mathrm{onset} \mathrm{of} \mathrm{heat.} \mathrm{Lowest}$ measurable value : $700 \mathrm{pg} / \mathrm{ml}$.

\section{Discussion.}

The increase of follicular radioactive $\mathrm{LH}$ binding indicated either an increment in the number of membrane receptors per cell or an increase in hormonal affinity, since the number of receptors did not vary. Kammerman and Ross (1975), Stouffer et al. (1976) and Lee (1976) showed that LH (or HCG) receptor affinity in sows did not vary during the different functional stages of the ovary. Increased binding thus probably indicates an increment in the number of receptors per cell.

Granulosa ${ }^{125}$-oLH binding was augmented by 14 times during the follicular phase in follicles whose diameter ranged from $2.6 \mathrm{~mm}$ (D0-D1) to $6.6 \mathrm{~mm}$ (D6).

These results confirm those of Kammerman and Ross (1975) and Nakano et al. 
(1977) who showed that granulosa HCG binding in the sow augmented 35 and 7 times, respectively, when the follicle enlarged from 1-2 $\mathrm{mm}$ to $6-12 \mathrm{~mm}$.

In the present report, no difference in ${ }^{125}$-oLH binding was found between the external and internal layers of the granulosa. The situation may be different in vivo since the incubation technique used in this experiment $\left({ }^{\mathbf{1 2 5}}\right.$-oLH applied directly to the section) did not take into consideration the follicular wall, a physiological barrier limiting follicular permeability (Szöllösi ef al., 1978). Thus Amsterdam ef al. (1975), simulating physiological conditions by administering iodinated HCG, showed differential binding between the inner and outer granulosa cells.

Labelling intensity on the theca interna increased by a factor of 2 between DO-D1 and D6, confirming the results of Rajaniemi and Vanha-Pertfula (1972) on mice and those of Midgley (1973) on rats.

The binding of ${ }^{125}$-oLH to the theca interna and the granulosa remained high after the ovulatory surge had ended, that is, for several hours before ovulation. But Tata (1975) suggested a general mechanism implicating the hormones in the regulation of their own receptor : a loss of $L H(H C G)$ receptors in the rat testis and ovary have been observed at about from hour 10 to hour 96 after injection of high doses of HCG (Sharpe, 1976 ; Haour et al., 1977 ; Lee and Ryan, 1973 ; Conti et al., 1976 ; Siebers et al., 1977). The ovulatory LH surge would also induce the loss of its own receptors in the luteinizing granulosa cells (Richards and Midgley, 1976). The 2 sows studied after the end of the ovulatory surge showed no receptor loss due to a strong dose of LH. Therefore, the phenomenon described in rats cannot be generalized.

The results of plasma LH assay in this sfudy agree with those of Niswender ef al. (1970), Hendricks ef al. (1972) and Guthrie et al. (1972). Intrafollicular LH concentration augmented at D5, while high plasma LH levels were found on D6 during the ovulatory discharge. After this surge, intrafollicular $\mathrm{LH}$ levels decreased again. The cause of this change in permeability is not known.

Intrafollicular estradiol-17ß level increases at D2 (Gérard et al., 1979). This synergistic rise with the increased intrafollicular FSH level described by McNatty ef al. (1975) in woman could explain the elevation of granulosa ${ }^{125}$-oLH binding between D4 and D5- 6 by an increase in the number of $\mathrm{LH}$ receptors, as has been reported in rats (Zeleznick ef al., 1974 ; Richards ef al., 1976 ; Nimrod et al., 1977).

Granulosa LH binding and the levels of intrafollicular progesterone both appear to increase between D4 and D5. Moreover, the high levels of progesterone after the end of the ovulatory surge ( $32 \mathrm{hrs}$ after the onset of estrus) would result from granulosa LH binding which was still considerable at that stage (fig. 2).

Reçu en février 1979.

Accepté eñ ovril 1979.

Acknowledgements. I wish to thank Dr. C. Thibault for his advice and Drs. M. T. Hochereau-de Reviers, G. Kánn, P. Rombauts and D. Szöllösi for their scientific aid. Drs. M. Justisz and $Y$. Combarnous kindly donated the ovine and porcine LH.

Résumé. Nous avons étudié par la technique d'histoautoradiographie, l'évolution de la fixation de la LH sur le follicule de Truie, pendant la période préovulatoire. Le traitement de synchronisation d'œstrus par le méthallibure nous a permis de disposer d'un point de 
référence permettani de dater le début de la phase folliculaire de chaque truie utilisée. La fixation de la ${ }^{125} \mid$-oLH et de la ${ }^{125} \mid$-pLH sur les follicules dont les diamètres varient de $2,6 \mathrm{~mm}$ (aux jours 0 et 1 de la phase folliculaire) à $6,6 \mathrm{~mm}$ (au jour 6 ) augmente de 14 fois pour la granulosa et de 2 fois pour la thèque interne. La fixation de ces hormones reste élevée pendant et après la fin de la décharge ovulante de LH, au moins jusqu'aux quelques heures précédant l'ovulation. Les variations de concentrations de LH plasmatique et de LH intrafolliculaire ont été dosées par radioimmunologie. Les concentrations élevées en estradiol-17 $\beta$ intrafolliculaire à partir du jour 3 expliqueraient la forte augmentation de la fixation de la LH sur la granulosa entre les jours 4 et 5-6, augmentation qui à son tour serait responsable de l'élévation du niveau de progestérone intrafolliculaire à partir du jour 5. Ces résultats semblent donc indiquer une interdépendance entre les niveaux hormonaux ef la réceptivité des cellules-cibles.

\section{References}

AMSTERDAM A., KOCK Y., LIEBERMAN E., LINDNER H. R., 1975. Distribution of binding sites for human chorionic gonadotrophin in the preovulatory follicle in the rat. J. Cell Biol., 67, 894-900.

CONTI M., HARWOOD J. P., HSUEH A. J. W., DUFAU M. L., CATT K. J., 1976. Gonadotropin induced loss of hormone receptors and densenzitization of adenylate cyclase in the ovary J. biol. Chem., 251, 7729-7731.

DAGUET M. C., 1978. Some aspects of final follicle growth in the sow. Ann. Biol. anim. Bioch. Biophys., 18, $1343-1349$.

GÉRARD M., MENEEZO Y., ROMBAUTS P., SZÖLLOSI D., THIBAULT C., 1979. In vitro studies of oocyte maturation and follicle metabolism in the pig. Ann. Biol. anim. Bioch. Biophys., 19, 1521-1535.

GUTHRIE H. D., HENRICKS D. H., HANDLIN D. L., 1972. Plasma estrogen, progesterone and luteinizing hormone prior to estrus and during early pregnancy in pigs. Endocrinology, 91, 675-679.

.HAOUR F., SANCHEZ P., GALLET D., SAEZ J. M., 1977. Désensibilisation par la gona dotropine chorionic humaine (HCG) : mise en évidence d'un contrôle négatif des récepteurs des gonadotropines par la HCG au niveau des cellules de Leydig du testicule. C. R. Acad. Sci. Paris, Sér. D, 284, 1429-1432.

HENRICKS D. M., GUTHRIE H. D., HANDLIN D. L., 1972. Plasma estrogen, progesterone and luteinizing hormone levels during the estrous cycle in pigs. Biol. Reprod., 6, 210-218.

HUNTER W. M., GREENWOOD F. C., 1962. Preparation of iodine-131 labelled human growth hormone of high specific activity. Nature, 194, 495-496.

KAMMERMAN S., ROSS J., 1975. Increase in numbers of gonadotropin receptors on granulosa cells during follicle maturation. J. clin. Endocrinol. Metab., 41, 546-550.

KANN G., 1972. Dosage radioimmunologique de la prolactine plasmatique chez les ovins. Possibilité d'adapter cette technique à la mesure de la prolactine humaine. In Techniques radioimmunologiques, Coll. INSERM, Paris, 149-172.

LEE C. Y. The porcine ovarian follicle. III. Development of chorionic gonadotropin receptors associated with increase in adenyl cyclase activity during follicle maturation. Endocrinology, 99, 42-48.

LEE C. Y., RYAN R. J., 1973. Interaction of ovarian receptors with human luteinizing hormone and human chorionic gonadotropin. Biochemistry, 23, 4609-4614.

MCNATTY K. P., HUNTER W. M., MCNEILLY A. S., SAWERS R. S., 1975 . Changes in the concentration of pituitary and steroid hormones in the follicular fluid of human graafian follicles throughout the menstrual cycle. J. Endocr., 64, 555-571.

MIDGLEY A. R., 1973. Autoradiographic analysis of gonadotropin binding to rat ovarian tissue sections, 365-378. In O'MALLEY B. W., MEANS A. R., Receptors for reproductive hormones, Plenum press, New York-London.

NAKANO R., AKAHORI T., KATAYAMA K., TOJO S., 1977. Binding of LH and FSH to porcine granulosa cells during follicular maturation. J. Reprod. Fert., 51, 23-27. 
NIMROD A., TSAFRIRI A., LINDNER H. R., 1977. In vitro induction of binding sites for HCG in rat granulosa cells by FSH. Nature, 267, 632-633.

NISWENDER G. D., REICHERT L. E., ZIMMERMAN D. R., 1970. Radioimmunoassay of serum levels of luteinizing hormone throughout the estrous cycle in pigs. Endocrinology, 87, 576-580.

POLGE C., 1965. Effective synchronization of oestrus in pigs after treatment with ICl Compound 33828. Vet. Rec., 77, 232-238.

RAJANIEMI H. J., VANHA-PERTTULA T., 1972. Specific receptor for LH in the ovary : evidence by autoradiography and tissue fractionnation. Endocrinology, 90, 1-9.

RICHARDS J. S., IRELAND J. J., RAO M. C., BERNATH G. A., MIDGLEY A. R., REICHERT L. E., 1976. Ovarian follicular development in the rat : hormone receptor regulation by estradiol, follicle stimulating hormone and luteinizing hormone. Endocrinology, 99, 1562-1570.

RICHARDS J. S., MIDGLEY A. R., 1976. Protein hormone action : a key to understanding ovarian follicular and luteal cell development. Biol. Reprod., 14, 82-94.

ROGERS A. W., 1961. A simple photometric device for the quantitation of silver grains in autoradiographs of tissue section. Exp. Cell Res., 24, 228-239.

SHARPE R. M., 1976. HCG-induced decrease in availability of rat testis receptors. Nature, 264, 644646.

SIEBERS J. W., PETERS F., ENGEL W., 1977. Ovarian HCG binding capacity during the oestrous cycle of the rat. Acta endocr., 85, 850-854.

STOUFFER R. L., TYREY L., SCHOMBERG D. W., 1976. Changes in [125] labeled human Chorionic Gonadotropin (HCG) binding to porcine granulosa cells during follicle development and cell culture. Endocrinology, 99, 516-524.

SZÖLLOOSI D., GÉRARD M., MÉNÉZO Y., THIBAULT C., 1978. Permeability of ovarian follicle, corona-cell-oocyte relationship in mammals. Ann. Biol. anim. Bioch. Biophys., 18, 511-521.

TATA J. R., 1975. Hormonal regulation of hormone receptors. Nature, 257, 740-741.

TERQUI M., DRAY F., COTTA J., 1973. Variations de la concentration de l'œstradiol $17 \beta$ dans le sang périphérique de la brebis au cours du cycle œestral. C. R. Acad. Sci. Paris, Sér. D, 277, $1795-1798$.

ZELEZNICK A. J., MIDGLEY A. R., REICHERT L. E., 1974. Granulosa cell maturation in the rat : increased binding of human chorionic gonadotrepin following treatment with follicle stimulating hormone in vivo. Endocrinology, 95, 818-825. 